\title{
Giving to Organizations that Help People in Need: Differences Across Denominational Identities
}

\author{
MARK OTTONI-WILHELM \\ Department of Economics, IUPUI and \\ Center on Philanthropy at Indiana University
}

\begin{abstract}
This article uses multiple-year data to examine charitable giving to organizations that help people in need of food, shelter, or other basic necessities. Families that give to basic necessity organizations in any single year are a mix of occasional givers and regular givers. Controlling for family characteristics that affect giving, giving to basic necessity organizations does not vary across Christian denominations and nonaffiliated families in any notable way. However, Jewish families are both more likely to give and, when they do give, give larger amounts. Given recent policy interest in how churches, synagogues, and mosques help with the voluntary provision of a safety net for people in need, the results draw attention to the importance of a research agenda focused on the differences between occasional givers and regular givers and on explaining why Jewish families give more to organizations that help people in need.
\end{abstract}

\section{INTRODUCTION}

Many previous studies have considered the role of religion in influencing giving to support churches, synagogues, and mosques ("religious" giving), and a few studies have considered charitable giving to "all other" organizations aggregated together (e.g., human service organizations, educational institutions, medical research, etc.). However, religious traditions define "charity" specifically as caring for people who are poor. Caring for people who are poor is advocated through the establishment of obligation-as in the Jewish obligation of tzedekah and the Muslim pillar of zakat — and the encouragement of generosity—as in the Jewish encouragement of gemilut hasadim and the Muslim encouragement of sadaqat. Despite religious traditions' emphasis on caring for people who are poor, only one previous study has examined giving specifically to organizations that help people in need (Regnerus, Smith, and Sikkink 1998).

This article reports the results of an analysis of charitable giving to basic necessity organizations that help people in need of food, shelter, or other basic necessities (e.g., Feeding America, the local food bank or homeless shelter, Habitat for Humanity, etc.)—and asks whether giving to such organizations varies across denominational identities. I answer this question using data from three waves of the Center on Philanthropy Panel Study, a module within the Panel Study of Income Dynamics (PSID) that enables three innovative analyses. The Center Panel is the first survey to collect data on dollar amounts given specifically to necessity organizations, enabling an

Acknowledgments: An earlier version of this article was presented at the 2008 Annual Meeting of the Society for the Scientific Study of Religion. I thank Stephanie Boddie, Eleanor Brown, Ram Cnaan, Bill Enright, Russell James, Una Osili, Dawn Ottoni-Wilhelm, David Sikkink, Chris Smith, and three anonymous referees for helpful comments. I am grateful for generous financial support from the Lake Institute on Faith and Giving, and for helpful comments from the Lake Institute Research Committee. Thanks also go to Atlantic Philanthropies, the Bill and Melinda Gates Foundation, and the John Templeton Foundation whose major financial support funds the collection of the data in the Center on Philanthropy Panel Study.

Correspondence should be addressed to Mark Ottoni-Wilhelm, Department of Economics, IUPUI, Indianapolis, IN 46202-5140.E-mail: mowilhel@iupui.edu 
analysis of the magnitude of giving as well as the probability of giving. Moreover, it is possible to estimate dollar amounts given beyond what people with denominational identities give to their church, synagogue, mosque, or other place of worship. In addition, because the Center Panel is part of the PSID, how giving to necessity organizations differs across families with different denominational identities can be estimated using regressions that contain high-quality controls for differences in families' income and wealth. This is important because income and wealth differ across denominational identities (Keister 2003, 2008) and failure to adequately control for income and wealth would lead to spurious findings. Finally, the Center Panel prospectively collects multiple years of giving data, enabling us to present the first analysis of giving to necessity organizations over a multiple-year period. This is important because there likely is a strong year-to-year dynamic in giving to necessity organizations, just as there is in aggregate giving (Rooney, Brown, and Wu 2007).

There are three main results. First, a statistical picture describing giving to basic necessity organizations in a single calendar year hides important facts that can only be uncovered with a multiyear description. For example, 29 percent of American families give to necessity organizations in a single calendar year, but a multiyear description shows that 30 percent of this group are "occasional" givers who give in only one of the three years while 33 percent are "regular" givers who give in all three years. Second, giving to necessity organizations does not vary across Christian denominations and nonaffiliated families in any notable way. That is to say, looking beyond amounts given to churches, there are no differences in giving to necessity organizations between mainline Protestant families and evangelical Protestant families, between Protestant families and Catholic families, or between Protestant/Catholic families and nonaffiliated families. Third, giving to necessity organizations varies by denominational identity in one main way. In regression-based models that control for income, wealth, and other characteristics of families, Jewish families are both more likely to give (by 8 percentage points) and when they do give, give larger amounts (20 percent more).

\section{Previous Research About Giving to Help People Who are Poor}

Regnerus, Smith, and Sikkink (1998) conducted the only study about the influence of religion on giving to help people who are poor. Using data from the 1996 Religious Identity and Influence Survey, they found evidence that evangelical Protestants who attend church frequently are more likely to have frequently "given money to an organization that helps poor and needy people" than a reference group of fundamentalists, mainline Protestants, low-attendance evangelicals, lowattendance Catholics, other religious identities, and those not religious. The Religious Identity Survey did not ask respondents about the magnitude of dollar amounts given.

A few studies have asked about the influence of religion on giving to charities other than churches, synagogues, and mosques, often called "secular" giving. These aggregate all giving, combining giving to help people in need with other kinds of giving, such as giving to educational institutions, medical research organizations, and the arts. Writing about the association between a person's participation in a religious organization and her secular giving, Wuthnow (1991:126) concludes that religious participation "has a genuine, but limited, effect on charitable behavior." Brown and Ferris (2007) also find a positive, though modest, association between the importance the respondent places on religion and her secular giving. However, their more important finding is

\footnotetext{
${ }^{1}$ In contrast, Brooks (2006:39, Ch. 2) argues that frequent religious attendance (every week or more) has a strong effect on secular giving. But his argument is not well supported by his evidence—only a single data set and a single regression. The regression has to make do with a low-quality income control and no wealth controls, and standard errors are not reported. In another regression (2006:197, Table 14, column 3), Brooks's estimates indicate no significant difference (statistical or economic) between every-week-or-more attenders and others.
} 
that the modest association is due entirely to a respondent's embeddedness in social networks and norms concerning trust. Evidence indicates no relationship between religious service attendance and secular giving in experiments (Bekkers 2007; Eckel and Grossman 2004). Bekkers and Schuyt (2008) analyze giving in the Netherlands and find no relationship between religious service attendance and secular giving, although they do find an association between denominational identity and secular giving, with Protestants giving more than Catholics. ${ }^{2}$

\section{Conceptual Framework}

\section{A Theory of Denominational Differences in Giving to Organizations that Help People in Need}

A denomination may have an effect on its members' giving to organizations that help people in need because of (i) the amount of emphasis the denomination places on the normative value of caring for people in need and alleviating the suffering caused by poverty, and (ii) the effectiveness of that emphasis in persuading a member to be generous. A systematic analysis of the amount of emphasis different denominations place on caring for people in need in denominational statements about giving, worship services, and in religious education would be a large (albeit important) undertaking, but this has not been done. Therefore, in their theoretical framework Regnerus, Smith, and Sikkink (1998) took the stronger emphasis mainline Protestant denominations and the Roman Catholic Church traditionally have placed on social reform to alleviate poverty as a proxy indicator of the amount of emphasis those denominations place on encouraging their members to be personally generous to organizations that help people in need. From that theoretical perspective, their empirical result that frequently attending evangelical Protestants are more likely to give to organizations that help people in need is quite surprising.

However, there has been no theoretical attention paid to how denominations might differ in their effectiveness in persuading a member to be generous. The framing used in appeals certainly matters (e.g., see Lakoff 2002), and obviously a denomination using more effective frames to promote generosity would be expected to generate more generosity in its members. A systematic analysis of the effectiveness of frames used by denominations to promote generosity to help people in need is not available. By examining the 35 denominational statements about giving collected by Smith, Emerson, and Snell (2008: Appendix A), I take a step toward such an analysis. The theoretical approach is to evaluate the statements using criteria drawn from social science literature about what encourages generosity and how to promote generosity. The causes of generosity include: (i) wanting to increase the well-being of people in need (altruism); (ii) wanting the positive feelings that come from acting consistently with one's self-identity as a generous person, or by gaining the approbation of others in one's community (empathy-specific reward); and (iii) wanting to avoid guilt by acting consistently with one's self-identity as a generous person or to avoid the shame of disapproval by one's community (see Batson 1991; Dovidio et al. 2006).

Therefore, generosity can be evoked, respectively, by framing denominational statements to make an empathic connection with people in need, to state that generosity is a necessary part of one's religious identity, and to establish generosity as a norm within one's community. There is extensive evidence from social psychology supporting the empathy-altruism hypothesis that empathic arousal evokes altruism that in turn encourages generosity (Batson 1991, 1998). In line with this, evidence from developmental psychology indicates that other-oriented induction

\footnotetext{
${ }^{2}$ There is also a large literature on whether religion promotes prosocial behavior broadly defined (e.g., Saroglou et al. 2005; Spilka et al. 2003: Ch. 14; Tan 2006). Although analysis of the association between religiosity and prosocial behavior broadly defined clearly is of interest, none of this literature focuses on giving to help people in need.
} 
(prosocial behavior encouraged by appeals that the behavior will improve the life of the other) -is more effective than duty-based appeals that one "should" behave prosocially because it is the "right thing to do" (e.g., Eisenberg and Fabes 1998; Eisenberg-Berg and Geisheker 1979; Grusec 1991).

Across social science disciplines, identity is regarded as a determinant of prosocial behavior (e.g., Aquino and Reed 2002; Bénabou and Tirole 2006; Dovidio et al. 2006:159ff). Internalizing a responsibility and duty to help others in need is the most advanced stage in the development of prosocial moral reasoning (Eisenberg and Mussen 1989). Hoffman (2000) calls this internalized duty the "principle of care," and that principle must be extended universally to all people for one to feel responsibility to help others outside one's own "in-group" (e.g., see Oliner and Oliner 1988; Schwartz 1992). Wilhelm and Bekkers (2010) further argue that such universalism is important especially for help channeled through organizations, and find evidence that endorsing a universal principle of care is associated with 10 different helping behaviors, including giving to a charity.

Community norms are regarded as determinants of prosocial behavior (e.g., Dovidio et al. 2006:115-17; Lévy-Garboua, Meidinger, and Rapoport 2006:581ff; Oliner and Oliner 1988). The desire for approbation from one's community is among the most powerful of motivators (Smith [1759] 1976). Supporting evidence from developmental psychology indicates that praising children for their prosocial behavior promotes further prosocial behavior, but the praise must attribute the child's prosocial behavior to her identity (Grusec and Redler 1980; Mills and Grusec 1989). Community norms are communicated powerfully by example; the most robust experimental result about prosocial behavior is that role-modeling a desired prosocial behavior effectively promotes the behavior (Eisenberg and Fabes 1998; Grusec 1991).

Applying this literature would suggest a denomination should connect its members empathically with people in need, frame generosity as a necessary part of a member's religious identity, and establish generosity as a norm within the denomination. However, an analysis of the denominational statements collected in Smith, Emerson, and Snell (2008) suggests that denominations do not fare well according to these criteria. ${ }^{3}$ None of the 35 statements frame generosity as a part of one's religious identity; no statement suggests that if one is not generous one is not a Christian. Indeed, only four of the 35 statements can be interpreted as saying that generosity is a matter of one's religious identity (e.g., "We cannot be true servants of God and let our lives be ruled by desire for wealth," (Smith, Emerson, and Snell 2008:219) or "The maturing disciple is also maturing in financial stewardship" (2008:216)). These statements do not frame generosity as a core part of religious identity by saying something like: "A Christian is someone who gives to help people who are poor - and that is the beginning and end of the matter."

Furthermore, none of the 35 statements use empathic other-oriented induction. Only 13 statements reference the needs of others in any way, and although it could be argued that these 13 are implicitly universal appeals (e.g., meant to include others outside the denomination), only one statement is explicitly universal (2008:221). One might argue that the very existence of the statements implicitly suggests a generosity norm within the religious community, but nothing in the statements suggests the norm is strong. Rather, 13 statements use language that may undercut the establishment of a community norm, for example, by "urging" members to be generous (rather than stating an expectation that all members "will" be generous), or saying that members "should" be generous (rather than saying members "must" be generous). Only four statements use role-model examples (e.g., Christ or the early church). Smith, Emerson, and Snell (2008:97) reach the same conclusion about the absence of strong community norms for generosity.

\footnotetext{
${ }^{3}$ The statements are mostly from evangelical and mainline Protestant denominations as well as the Roman Catholic and Greek Orthodox Churches. Nondenominational churches are not included so the theoretical framework may not apply to them.
} 
If the denominational statements do not use frames known from the social science literature to be effective, then how do the statements attempt to persuade members to be generous? The arguments most frequently used frame giving as based in stewardship, duty, and reciprocity. The stewardship frame that all material things belong to God and that people are stewards, not owners, may not be persuasive in a society where people are accustomed to daily acting as owners and thinking of themselves as owners-owners of appliances, bank accounts, cars, houses, businesses, land, etc. As argued above, appeals to duty are weaker than empathic other-oriented induction, but the statements' appeals to duty are especially weak because they do not frame that duty as a part of the member's religious identity. A denomination's use of direct reciprocity may be an effective frame to persuade a member to give back to the church (i.e., God gave to you so you should repay God). A specific example comes from Smith et al.: "The tithe is . . an opportunity for grateful response to God's grace" (2008:198). But there is no evidence that using generalized reciprocity (Ekeh 1974) is an effective frame to persuade a member to give to organizations that help people in need (i.e., God gave to you so you should repay God's gift by giving to help others). ${ }^{4}$

In short, in trying to persuade members to be generous, none of the 35 Christian denominations use frames known to be effective, and instead are using frames whose effectiveness is, at best, questionable. Because of this lack of effectiveness across denominations, I hypothesize no large differences in giving to basic necessity organizations across different Christian denominations. Neither do I expect differences between the Christian denominations taken all together and nonaffiliated families.

In contrast to the statements from Christian denominations, the literature on Jewish philanthropy uses appeals to be generous that align well with the effective frames from the social science literature. Jewish philanthropy makes use of empathic other-oriented induction by connecting the needs of people who are poor to the Jewish history of enslavement in Egypt (e.g., Dorff 2005:41-42), and by framing poverty as death while tzedekah "saves from death" (e.g., Bush and Dekro 1993:113-14). The literature on Jewish philanthropy emphasizes that giving to help people with basic needs is an essential part of Jewish identity (Dorff 2005:1-3, 42ff; Neusner 1982; Silverman 1991; Tobin 2001; Woocher 1986:84-87). Tobin (2001:7-8) writes: "what distinguishes tzedakah ... [is that] ... it is a must, not a should ... [It] is deeply embedded in Jewish thought and feeling, especially the imperative to provide for basic human needs." Neusner (1982:32) writes: "A Jew is someone who participates in tzedakah-and that is the beginning and end of the matter" (see also 1982:28, 68). Also, the Jewish philanthropy literature emphasizes universalism, that giving is to help people in need, both Jews and non-Jews (Dorff 2005:37, 41ff, 125, 130; Neusner 1982:24-26; Ritterband 1991:71; Silverman 1991; Tobin 2001:7-8, 17-18; Woocher 1986). Finally, the Jewish philanthropy literature emphasizes a strong community norm behind giving (Heilman 1991; Neusner 1982:67ff; Ritterband 1991:60; Tobin 2001:8-9; Woocher 1986:85). Because of this alignment between the Jewish philanthropy literature and effective frames from the social science literature, I hypothesize that there may well be a difference between Jewish families and other families in giving to organizations that help people with basic necessities, with Jewish families giving more. ${ }^{5}$

\footnotetext{
${ }^{4}$ Evidence offered in support of generalized reciprocity (e.g., Dovidio et al. 2006:112) can be alternatively interpreted as role-modeling. It is difficult empirically to distinguish generalized reciprocity from role-modeling, but in an investigation of important intergenerational help between members of the same family (co-residence and financial support), the evidence is consistent with role-modeling, not generalized reciprocity (Ribar and Wilhelm 2006).

${ }^{5}$ A reviewer suggests the Christian philanthropy literature may contain similar statements. While an exhaustive search of the Christian philanthropy literature is beyond the scope of this article, similar statements are not easily found in the mainstream literature. Giving to help people who are poor is framed not as an imperative, but in terms of a calling/invitation. For example: "Every Christian is called to practice this charity." (Pope Benedict XVI 2009) and "I invite you to take the
} 


\section{Selection}

The denomination's effectiveness in encouraging giving is a casual mechanism by which families with one denominational identity may be expected to differ (or not) in giving to necessity organizations compared to families with another denominational identity. The evidence offered here, however, is descriptive, meaning that should families with one denominational identity be more generous than families with another denominational identity it will be difficult to tell whether this is because of the denomination's effectiveness at encouraging giving or because of the selection of people into those denominations. Of course, should I find no difference, the possibility of selection processes operating would be less plausible. Moreover, selection would be a less plausible explanation should differences be found between certain pairs of identities, for example, between Jewish families and other families.

\section{Attendance}

Although the main research question is about differences in giving across denominational identities, I also examine interactions between denominational identity and frequent religious service attendance. Interacting denominational identity and attendance splits the families within each denominational identity into two groups: frequent and infrequent attenders. However, while frequent attendance implies repeated exposure to a wide range of denominational values, it does not necessarily imply reception of the value of caring for people in need. Neither does infrequent attendance necessarily imply the denial of that value.

Moreover, while frequent attendance does capture exposure to denominational emphasesand, more generally, captures a person's more intense religiosity-attendance likely captures more than just exposure to emphases and religiosity. Attendance likely captures other unobserved characteristics of a person that are co-determinates of both attendance and giving, such as a general willingness to devote oneself to community activities, including alleviating poverty in one's community. Another unobserved characteristic is the number of times a person is asked by others to give to a charity. A frequent attender by definition places herself in a community activity (the worship service) where she can be asked to give, and she is more likely to be placing herself in other community activities at which she also can be asked to give. In short, attendance is a choice a person makes, and we should avoid making a causal interpretation of a correlation between one choice a person makes (giving) and another choice the person makes (attendance). Foreshadowing the results, attendance tells us something about the unobserved characteristics of people, but what attendance tells us is different for evangelical Protestants than it is for mainline Protestants.

\section{Methods}

The data are from the 2001, 2003, and 2005 waves of the PSID (Stafford et al. 2005). The PSID's 1968 initial sample had a 76 percent response rate, the 1969 reinterview rate was 88.5 percent, and subsequent wave-to-wave response rates are 96-98 percent. The sample has been replenished though births and marriages (the PSID is a genealogical panel), the 1997 immigrant refresher, and the recontact effort for nonresponse families that began in 1992. A large number of PSID data-quality studies have been conducted, the overall conclusion from which indicates that the PSID is representative (e.g., Fitzgerald, Gottschalk, and Moffitt 1998; Gouskova and Schoeni 2007; Hill 1992).

following Generous Christian's pledge" (Sider 1999). Jackson (2003) reaches the same conclusion, writing that "private charity is now frequently thought admirable but morally optional." 


\section{Giving to Basic Necessity Organizations}

The PSID's philanthropy module (the Center on Philanthropy Panel Study) measures charitable giving (Wilhelm et al. 2005). The quality of the Center Panel giving data is high. The questions produce very little missing data and the distribution of giving is consistent with IRS data on charitable deductions and the 1974 National Study of Philanthropy (Wilhelm 2006, 2007).

Respondents are specifically asked about the amount their family gives to organizations that help people in need of basic necessities (bold emphasis in the original questionnaire):

\section{Did you [or anyone in your family] make any donations (during 2004) to organizations that help people in need of food, shelter, or other basic necessities?}

[If yes] What was the total dollar value of all donations you [and your family] made in 2004 to organizations that help people in need of basic necessities?

The survey question is very well suited to answering the research question. To my knowledge, this is the only survey question that asks respondents specifically about amounts given to organizations that help people in need and separates this giving from voluntary giving to a wide variety of other organizations (e.g., education, medical research, the arts, etc.). Because of this design, we know that all the giving reported in response to the question is given to help people who are poor.

Even so, the survey question may not capture all the giving to charitable organizations done by families that help people in need. First, the question does not capture giving to churches, synagogues, and mosques that is in turn used by congregations to help people in need. However, the amount of this giving is small and concentrated in a small number of congregations (Smith, Emerson, and Snell 2008). ${ }^{6}$ Second, a family may give through a special collection at their congregation for the specific purpose of providing for the basic necessities of people in need. The Center Panel religious giving question instructs respondents not to report giving to charities run by religious organizations as giving to their congregations. But respondents may not make such distinctions if the congregation is doing the collecting, especially if the amounts are small. The Center Panel does collect information about whether donations are given to help the victims of the December 2004 tsunami through a place of worship. I use the tsunami-donations-through-worship data to conduct three checks of the potential severity of the special collections problem.

Third, families give to organizations like the United Way that fulfill a combination of purposes, some of which include helping people who are poor (Rooney and Brown 2007). Similarly, giving to international aid organizations obviously helps people who are poor (Okten and Osili 2007). Therefore, I check the sensitivity of my main results about giving to basic necessity organizations by adding to this the amounts given to combined purpose and international aid organizations.

Finally, families sometimes help people who are poor by giving, not through organizations, but directly to the people themselves. Almost all giving directly to people is intrafamily and much of it is transfers made by high-income parents to their lower-income (though not "poor") children (Schoeni 1997). Hence, direct monetary giving to people who are poor is very small and its absence from the analysis is not likely to introduce error.

\footnotetext{
${ }^{6}$ The exact percentage of giving to congregations to help people in need is unknown. An upper bound can be set by taking Hodgkinson and Weitzman's (1992:75) estimate that 13.9 percent of congregational expenditures are donations to organizations and individuals plus an assumption that all of that expenditure goes to help people in need. Biddle (1992) calculated a much smaller amount of 6 percent. Chaves's (2004) evidence that congregations provide relatively small amounts of social services would seem to suggest that the percentage of congregational expenditure for helping people in need is low. Smith, Emerson, and Snell put the figure at 4 percent (2008:52-55).
} 
The Center Panel has three advantages that likely mitigate social presentation effects. First, the Center Panel begins with a screening question that asks whether the family donated "more than $\$ 25$ to religious or charitable organizations" (emphasis in the questionnaire). This gives respondents a socially acceptable way to say "no," and nearly one-third of the sample do say "no." Second, the Center Panel asks about giving to nine different types of organizations plus one open-ended giving question, easing social presentation effects on any one question. Third, social presentation effects are eased because participants regard the PSID as a survey mostly about family economics, not as a survey about giving and religion. Furthermore, the giving questions occur well after the denominational identity questions, in most cases many years after. ${ }^{7}$

\section{Denominational Identity}

The PSID queries denominational identity with two questions: religious preference and, if Protestant, denomination. Both questions are asked when a new family forms by either (i) a child creating a new family by leaving his/her family of origin, (ii) formation of a new couple through marriage or cohabitation, or (iii) a divorce or separation of a couple. Data are reported for both men and women in couples. For couples the religious preference and denomination of the man are used. ${ }^{8}$

The PSID data permit an approximate, though not exact, mapping into the Steensland et al. (2000) mainline-evangelical-black Protestant categories. The PSID codes all Lutherans together: Missouri Synod (Steensland et al. classification is evangelical), Wisconsin Evangelical Lutheran Synod (evangelical), and the Evangelical Lutheran Church in America (mainline); because the Evangelical Lutheran Church in America has more members I map all PSID Lutherans into the mainline category. An assessment of the PSID mapping using the 1996-2006 General Social Survey (GSS, Davis and Smith 2007) indicates that only about 7 percent of PSID Protestants are being classified differently than they would be if the exact Steensland et al. classification could be used. In addition, I check the sensitivity of the PSID results by replicating them with an analysis of the 1996 GSS data (which permit the exact Steensland et al. classification) on giving to human service organizations and international organizations. The GSS results suggest that the PSID approximate mapping is not causing a problem. To ease discussion throughout the rest of the article, I drop the qualifier "approximate" when discussing the mainline-evangelical-black categories.

\section{The Sample}

The analysis uses a three-year sample combining the PSID's 2001, 2003, and 2005 waves. The three-year sample begins with 8,002 PSID families responding to the 2005 interview, selects the head-of-household or (if married) the spouse (depending upon whether the head or spouse is the PSID sample member), and attempts to follow that person back through the 2001 wave. Among the 8,002 families, we can follow 6,527 back through the 2001 wave. The 1,475 families

\footnotetext{
${ }^{7}$ Some people may have switched denominations after the last query in the PSID, but before answering the giving questions. Although the recent Pew (2008) study documents a lot of religious switching, that study measures switching from the religion in which one was raised as a child, and not from the religion one had in young adulthood when the earliest PSID measures would have been taken. In fact, switching is a strong negative function of age (Sherkat 1991), with the large majority of switching occurring before age 36 (Pew 2009). Therefore, I check the sensitivity of my results to see whether they change when the analysis is restricted to the subsample of respondents whose denominational identity was queried when they were 36 years old or older. Results are also checked using data from the General Social Survey (GSS); in the 1996 GSS denominational identity and giving are queried in the same survey year so switching does not cause a problem.

${ }^{8}$ The results are similar if religious preference and denomination of the woman are used.
} 
Table 1: Comparing the 2004 and three-year samples

\begin{tabular}{lcc}
\hline Variable & 2004 Sample & Three-Year Sample \\
\hline Income in 2004 & 67,598 & 71,182 \\
Wealth, not home & 215,515 & 236,032 \\
Home equity & 102,561 & 113,583 \\
Age & 49.5 & 52.3 \\
Income in 2004; age 30 years or older & 72,517 & 72,950 \\
Wealth, not including home; age 30 years or older & 247,159 & 249,884 \\
Home equity; age 30 years or older & 117,355 & 120,169 \\
Less than high school & .163 & .163 \\
High school & .313 & .317 \\
Some college & .222 & .217 \\
College & .162 & .158 \\
Postcollege & .104 & .108 \\
Education missing & .034 & .037 \\
Working & .713 & .696 \\
Health is poor or fair & .221 & .237 \\
African American & .141 & .128 \\
Hispanic & .067 & .065 \\
Ethnicity missing & .061 & .053 \\
Couple & .546 & .572 \\
Single woman & .286 & .283 \\
No children living in family & .678 & .675 \\
Number of children & .593 & .609 \\
Age of youngest child & 2.381 & 2.538 \\
Lives in the south & .333 & .333 \\
Lives is a large city & .737 & .729 \\
Sample size & 7,535 & 6,105 \\
\hline
\end{tabular}

Note: The table presents descriptive statistics for the sample of 2004 families (column 1) and the three-year sample (column 2). Data are from the 2001, 2003, and 2005 waves (see footnote 10. The table shows that selecting the families that can be followed back three years (column 2) produces a sample with characteristics similar to the 2004 sample (column 1), except that the three-year sample is older. Each sample drops families not asked the Center Panel module, whose denominational identity is missing, who are Orthodox, or who are Liberal nontraditional. The three-year sample is the analysis sample used in the article. Income and wealth are measured at the family level. Age and other individualspecific characteristics are measured for the single-heads and the men in couple-families. The averages and fractions are weighted.

that cannot be followed all three years are mostly families newly formed during 2002-2005. Starting with the 6,527 three-year families, dropping the families not asked the Center Panel module $(n=168)$, whose denominational identity is missing $(n=226)$, who are Orthodox $(n=$ $13)$, or who are Liberal nontraditional $(n=15)$ leaves a three-year sample of 6,105 families. I drop Orthodox and Liberal nontraditional families because there are too few in the sample to conduct a meaningful analysis.

Table 1 presents descriptive statistics comparing the families followed back all three years to all the 2004 families. ${ }^{9}$ The families in the three-year sample are similar to the 2004 families, except that the three-year families are slightly older. Table 2 presents the fractions of the three-year sample with each denominational identity.

\footnotetext{
${ }^{9}$ The "2004 families" are the 8,002 families responding to the 2005 interview. Most PSID questions ask respondents to report amounts from the previous calendar year, so families responding to the 2005 interview report information about charitable giving and income for calendar year 2004.
} 
Table 2: Denominational identity in the three-year sample

\begin{tabular}{lcc}
\hline Denominational Identity & $\begin{array}{c}\text { Fraction of the Sample } \\
\text { (Weighted) }\end{array}$ & $\begin{array}{c}\text { Number in the Sample } \\
\text { (Not Weighted) }\end{array}$ \\
\hline All families & 1.00 & 6,105 \\
Nonaffiliated & .12 & 694 \\
Has a denominational identity & .88 & 5,411 \\
Black Protestant & .08 & 1,302 \\
Evangelical Protestant & .26 & 1,488 \\
Mainline Protestant & .19 & 864 \\
Catholic & .25 & 1,228 \\
Jewish & .03 & 125 \\
No-denomination Protestant & .05 & 225 \\
Conservative nontraditional & .02 & 103 \\
Muslim, Buddhist, and other & .01 & 77 \\
\hline
\end{tabular}

Note: The fractions in column 1 are weighted so that the fractions are unbiased estimates of population fractions-the weights are necessary to account for unequal probabilities of selection into the sample. Black Protestants: African Americans coded by the PSID as Baptist, Methodist/African Methodist, or Church of God. Evangelical Protestants: coded by the PSID as Baptist (non African Americans only), Church of God (non African Americans only), Pentecostal/Assembly of God, Protestant-Christian, Seventh Day Adventist, Reformed/Christian Reformed, Disciples of Christ/United Christian/First Christian/Christian Holiness, Churches of Christ, Amish/Mennonite, or Protestant unspecified/other Protestant and attend services once per month or more. Mainline Protestants: coded by the PSID as Episcopalian, Lutheran, Methodist/African Methodist (non African Americans only), Presbyterian, Quaker/Friends, or United Church of Christ/Congregational Church. No-denomination Protestant: coded by the PSID as Protestant unspecified/other Protestant and attend services less than once per month. Nondenominational Protestants are those coded as Protestant unspecified/other and who attend services once per month or more; we group nondenominational Protestants with evangelical Protestants. These decisions follow Steensland et al (2000:295-96). Conservative nontraditional: coded by the PSID as Latter Day Saints/Mormon, Jehovah's Witness, or Christian Science.

\section{RESULTS}

\section{Descriptive Statistics: Percent Who Give and Amounts Given over Three Years}

Statistics describing the fraction of families who give, and the amounts given over a three-year period paint a much different picture of giving than would appear from a single-year cross-section. Figures 1 and 2 present the single-year cross-section (2004) and three-year perspective (2000, 2002, and 2004). ${ }^{10}$ Figure 1 Panel A shows that in a single-year cross-section 29 percent of families give to basic necessity organizations, but 53 percent give at least once during the longer, three-year period. Panel B shows that in a single-year cross-section, among the 29 percent of families who give, the median gift is $\$ 200$ and the mean gift is $\$ 497$. However, among the 53 percent of families who give at least once during the three-year period, the "annualized" median and mean are smaller: \$105 and \$271. ${ }^{11}$

Figure 2 explains why the single-year amounts are larger than the three-year amounts, by examining the heterogeneity in the frequency of giving over three years. Figure 2 Panel A reports how frequently families who gave in 2004 also gave in all three years: 30 percent were

\footnotetext{
${ }^{10}$ The descriptive statistics are weighted estimates. The 2005 weights (Gouskova 2007) account for the unequal selection probabilities that brought families into the PSID (through either the nationally representative, the low-income, or the immigrant refresher subsamples) and for differential attrition. The regression-based estimates are from weighted regressions and weighted maximum likelihood.

${ }^{11}$ The average annual gift for each family who gave during the three years is calculated (i.e., the three-year total giving divided by three) and the median and mean across these families is reported.
} 
Figure 1

Fraction giving to basic necessity organizations and the amounts given: Comparing statistics from a one-year cross-section (2004) with a three-year perspective $(2000,2002,2004)$

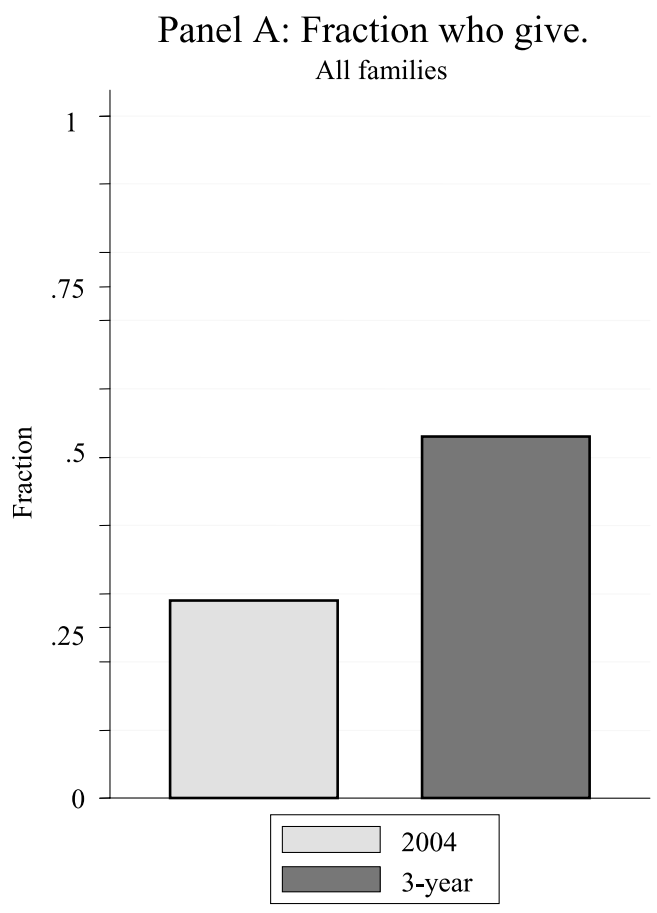

Panel B: Amount given.

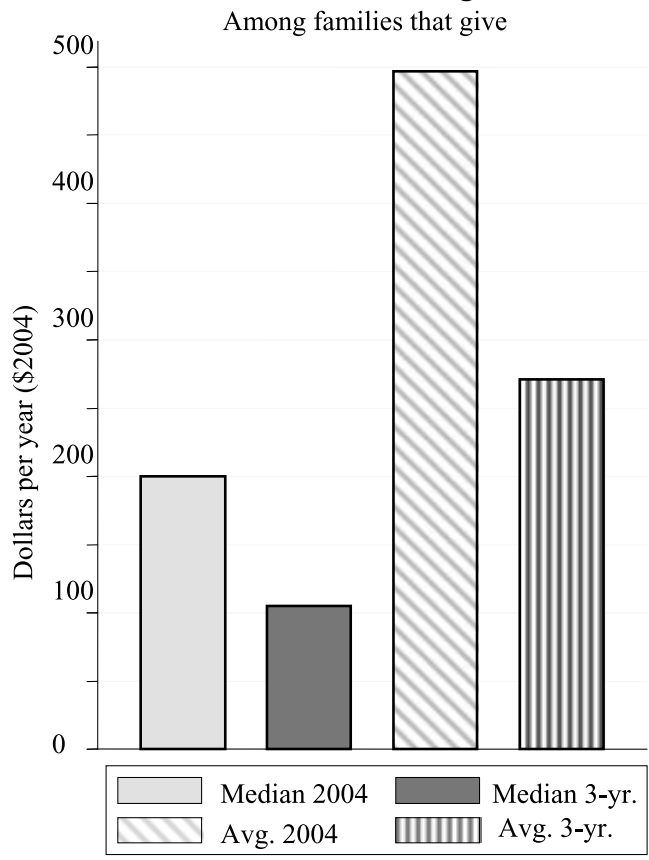

Figure 2

Heterogeneity in the frequency of giving over three years (2000-2004)

Set of 2004 givers

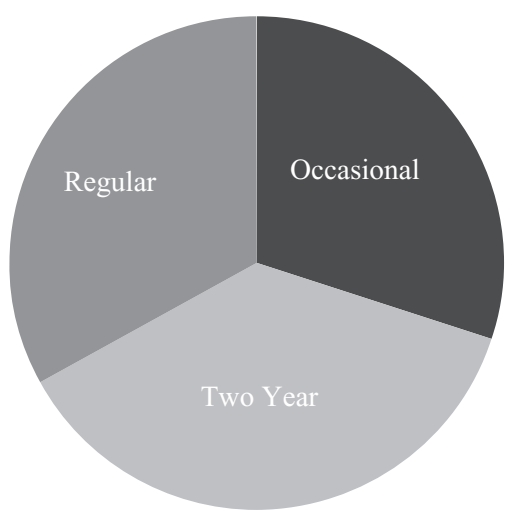

Set of 2000-2004 givers

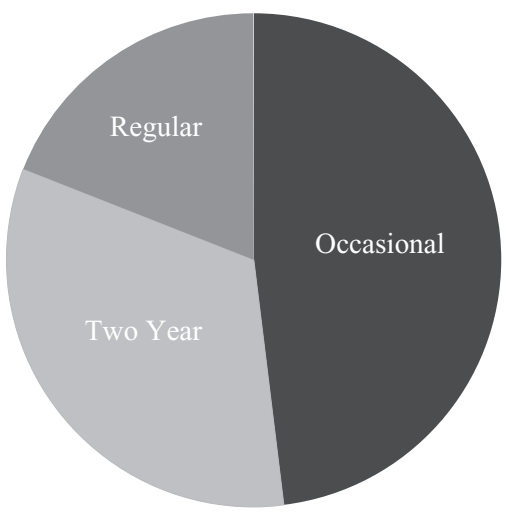

Note: Charts show the patterns over 2000-2004 of the two sets of givers.

"occasional" givers (that is, they did not give in 2000 or 2002), 37 percent gave in two of the three years, and 33 percent were "regular" givers, giving in all three years. Panel B reports how frequently families who gave at least once over the three-year period were occasional (48 percent), two-year (33 percent), and regular (19 percent) givers. 
The common tendency is to consider a one-year cross-section statistic-(e.g., 29 percent) as a static figure; families who give in one year presumably give every year. But, in fact, among the 29 percent there is a fairly equal mix of occasional and regular givers. On the other hand, if one considers givers who gave at least once over multiple years, a higher proportion of these multiyear givers are occasional givers. Among the single-year 2004 givers there is a higher proportion of regular givers and consequently the "conditional" amounts are higher because regular givers give more, even on an annual basis, than do occasional givers. ${ }^{12}$ The median and mean dollar amount given per year increases with the number of years that a family gives (not shown in the figures).

An analysis of giving across denominational identities using a one-year cross-section misses many occasional givers and possibly paints a misleading picture of denominational differences, especially if occasional givers are more prominent in some denominations than in others. Using the three-year giving data, there remain denominational differences in giving to basic necessity organizations in the simple statistics. For example, Jewish families give more in terms of the fraction who give (78 percent) and the conditional mean (\$552); and a lower fraction of black Protestant families (41 percent) and evangelical families (51 percent) give compared to mainline Protestants (60 percent). However, these differences do not control for income, wealth, education, and other variables that affect giving and are likely correlated with denominational identity.

\section{Tobit Models of the Amounts Given, Controlling for Income and Other Characteristics}

Table 3 presents estimates from Tobit models of giving. The dependent variable in column 1 is the logarithm of the per-year average amount given (averaged across the three years 2000, 2002, and 2004) to basic necessity organizations. The dependent variable in column 2 is expanded to include (in addition to necessity organizations) giving to combined purpose and international aid organizations. The Tobit estimates in column 1 estimate the marginal effects of the independent variables on the probability of giving (column 1a) and the marginal effects on the log amount given among families that give, that is, conditional on giving a positive amount (column 1b); similarly for column 2 .

The independent variables of primary interest are the indicators of denominational identity. The reference group is Catholic, selected as the omitted group because their simple statistics (52 percent give; conditional mean $=\$ 288$ ) are closest among denominational identities to the national average (53 percent give; conditional mean $=\$ 271$ ). The models also include variables controlling for income, wealth, education, cohort, being employed, health, ethnicity, race, being married, having children (and the number of children and the age of the youngest child), living in the south, and living in a big city ( $n=24$ observations have missing data on some of the controls and are not used in the models). Only the income and wealth controls are reported in the tables; estimates for the full set of control variables are available from the author.

Nonaffiliated and Jewish families are more likely to give than Catholic families; the probabilities are .049 and .081 higher and are statistically significant (the two-sided $p$-values are .05 and .04). The estimates can be interpreted directly as the marginal effect on the probability of giving (relative to Catholic families and hence the nationally average family). For example, the .081 higher probability of giving among Jewish families is 15 percent higher (.081/.53) than the national average of 53 percent, a fairly strong relationship.

The sensitivity of results is tested by estimating linear, probit, and logit models of the probability of giving (not shown, but available upon request). This permits a check on the sensitivity of the column 1a results by separating the effects of the amount given from the

\footnotetext{
${ }^{12}$ I make frequent reference to the mean and median amounts given among just those families who give, and refer to these as the "conditional mean" and "conditional median"- that is, mean and median amounts calculated after first "conditioning" on the set of families who give something.
} 
Table 3: Tobit models of amounts given over three years to organizations that help people with basic necessities

\begin{tabular}{|c|c|c|c|c|}
\hline \multirow[b]{2}{*}{ Independent Variables } & \multicolumn{2}{|c|}{$\begin{array}{l}\text { Giving to Basic Necessity } \\
\text { Organizations (1) }\end{array}$} & \multicolumn{2}{|c|}{$\begin{array}{c}\text { Giving to Basic Necessity, } \\
\text { Combined Purpose, and } \\
\text { International Aid } \\
\text { Organizations (2) }\end{array}$} \\
\hline & $\begin{array}{l}\text { Probability } \\
\text { of } \\
\text { Giving } \\
\text { (a) }\end{array}$ & $\begin{array}{l}\text { Log Amount } \\
\text { Conditional } \\
\text { on Giving } \\
\text { (b) }\end{array}$ & $\begin{array}{l}\text { Probability } \\
\text { of } \\
\text { Giving } \\
\text { (a) }\end{array}$ & $\begin{array}{l}\text { Log Amount } \\
\text { Conditional } \\
\text { on Giving } \\
\text { (b) }\end{array}$ \\
\hline Nonaffiliated & $\begin{aligned} .049^{*} \\
(.025)\end{aligned}$ & $\begin{aligned} .116^{*} \\
(.062)\end{aligned}$ & $\begin{array}{r}-.009 \\
(.019)\end{array}$ & $\begin{array}{r}-.035 \\
(.069)\end{array}$ \\
\hline Black Protestant & $\begin{array}{l}.002 \\
(.044)\end{array}$ & $\begin{array}{l}.004 \\
(.099)\end{array}$ & $\begin{array}{r}-.042 \\
(.033)\end{array}$ & $\begin{array}{r}-.147 \\
(.108)\end{array}$ \\
\hline Evangelical Protestant & $\begin{array}{l}.019 \\
(.022)\end{array}$ & $\begin{array}{l}.043 \\
(.051)\end{array}$ & $\begin{array}{l}.001 \\
(.015)\end{array}$ & $\begin{array}{l}.006 \\
(.057)\end{array}$ \\
\hline Mainline Protestant & $\begin{array}{l}.011 \\
(.023)\end{array}$ & $\begin{array}{l}.025 \\
(.052)\end{array}$ & $\begin{array}{r}-.014 \\
(.016)\end{array}$ & $\begin{array}{r}-.054 \\
(.057)\end{array}$ \\
\hline Catholic & - & - & - & - \\
\hline Jewish & $\begin{array}{l}.081^{* *} \\
(.039)\end{array}$ & $\begin{array}{l}.201^{*} \\
(.106)\end{array}$ & $\begin{array}{l}.058^{* * *} \\
(.020)\end{array}$ & $\begin{array}{l}.255^{* *} \\
(.104)\end{array}$ \\
\hline No-denomination Protestant & $\begin{array}{l}.037 \\
(.037)\end{array}$ & $\begin{array}{l}.087 \\
(.090)\end{array}$ & $\begin{array}{c}-.008 \\
(.026)\end{array}$ & $\begin{array}{r}-.030 \\
(.095)\end{array}$ \\
\hline Conservation nontraditional & $\begin{array}{l}.046 \\
(.056)\end{array}$ & $\begin{array}{l}.109 \\
(.141)\end{array}$ & $\begin{array}{l}.025 \\
(.035)\end{array}$ & $\begin{array}{l}.099 \\
(.150)\end{array}$ \\
\hline Muslim, Buddhist, other & $\begin{array}{l}.043 \\
(.054)\end{array}$ & $\begin{array}{c}.102 \\
(.134)\end{array}$ & $\begin{array}{l}.044 \\
(.041)\end{array}$ & $\begin{array}{l}.188 \\
(.195)\end{array}$ \\
\hline Log 2000-2004 income & $\begin{array}{l}.153^{* * *} \\
(.015)\end{array}$ & $\begin{array}{l}.348^{* * *} \\
(.034)\end{array}$ & $\begin{array}{l}.159^{* * *} \\
(.012)\end{array}$ & $\begin{array}{l}.604^{* * *} \\
(.044)\end{array}$ \\
\hline $\begin{array}{l}\text { Log } 2004 \text { wealth } \\
\quad \text { (not including home equity) }\end{array}$ & $\begin{array}{l}.031^{* * *} \\
(.005)\end{array}$ & $\begin{array}{l}.070^{* * *} \\
(.011)\end{array}$ & $\begin{array}{l}.024^{* * *} \\
(.004)\end{array}$ & $\begin{array}{l}.091^{* * *} \\
(.014)\end{array}$ \\
\hline Log 2004 home equity & $\begin{array}{l}.013 \\
(.008)\end{array}$ & $\begin{array}{l}.030 \\
(.019)\end{array}$ & $\begin{array}{l}.012^{* *} \\
(.006)\end{array}$ & $\begin{array}{l}.044^{* *} \\
(.021)\end{array}$ \\
\hline $\begin{array}{l}\text { Pseudo } R^{2} \\
\text { Sample size }\end{array}$ & & $\begin{array}{l}83 \\
81\end{array}$ & & \\
\hline
\end{tabular}

Note: In column 1, the dependent variable is the logarithm of the three-year average $(2000,2002$, and 2004) of giving to organizations that help people in need of food, shelter, or other basic necessities. In column 2, the dependent variable is expanded to include giving to combined purpose and international aid organizations. The independent variables are those shown in the table plus controls for education, cohort, being employed, health, ethnicity, race, being married, having children (and the number of children and the age of the youngest child), living in the south, and living in a big city. For estimates on controls contact the author. The estimates are from weighted Tobit models. The results in column 1 are from a single set of Tobit estimates used to estimate the marginal effect on the probability of giving (column 1a) and the marginal effect on the log amount given, conditional on that amount being greater than zero (column 1b). Similarly, the results in column 2 are from a single set of Tobit estimates with the expanded definition of giving.

The pseudo $R^{2}=1-\mathrm{L}_{1} / \mathrm{L}_{0}$ where $\mathrm{L}_{1}$ is the log-likelihood of the model and $\mathrm{L}_{0}$ is the log-likelihood of a model with only the constant term. The sample size $(n=6,081)$ is slightly smaller than in Tables 1 and 2 because 24 families have missing data for some of the control variables.

${ }^{*} p<.10 ;{ }^{* *} p<.05 ;{ }^{* * *} p<.01$. 
estimates used to calculate the marginal effects on the probability of giving. The results are similar to results reported in Table 3, column 1a. For example, the probability that Jewish families give is estimated to be .066 higher than Catholic families $(p=.14)$ in the linear probability model, $.097(p=.11)$ in the probit model, and $.100(p=.12)$ in the logit model. The two-sided $p$-values indicate that the hypothesis that Jewish families and Catholic families are equally likely to give cannot be rejected at a conventional 10 percent significance level, but some readers may still view the evidence from the probability models as statistically important in light of the relatively small numbers of Jewish families in the sample $(n=125)$. Moreover, the one-sided hypothesis that Jewish families are less or equally likely to give than Catholic families can be rejected at conventional levels (e.g., $p=.07$ in the linear probability model).

The estimates in column $1 \mathrm{~b}$ (Table 3 ) indicate that nonaffiliated and Jewish families give higher amounts (conditional on giving) than Catholic families: 11.6 and 20.1 percent higher. The 20.1 percent higher giving among Jewish families applied to the national average (\$271) implies \$54 per year higher giving, again a fairly strong relationship. Differences between black, evangelical, and mainline Protestant and Catholic families are close to zero and not statistically significant. I checked the sensitivity of results by estimating a least absolute deviations model and a least squares model just on the families who gave at least once (over 2000, 2002, and 2004) to necessity organizations ( $n=2,907$; results not shown but available upon request). The results are similar to column $1 \mathrm{~b}$ (Table 3 ). For example, conditioning on families who give, the median amount given by Jewish families is estimated to be 23.6 percent higher than the median amount given by Catholic families $(p=.07)$, and the average amount given is 21.4 percent higher $(p=$ $.15)$.

Although not shown directly in Table 3, similar differences are seen when Jewish families are compared to other families. For example, the Jewish-mainline difference in giving to necessity organizations is .071 in probability $(p=.08)$ and 17.4 in percentage amounts $(p=.10)$. The difference between Jewish families and evangelical Protestant families is slightly smaller, .064 in probability $(p=.12)$ and 15.4 in percentage amounts $(p=.14) .^{13,14}$

Again, although not directly shown in Table 3, I checked each pair of denominational identities (including the "not affiliated" identity), and found no statistically significant differences. For instance, the Conservative nontraditional-black Protestant difference in the probability of giving is .044 , but the $p$-value is .52. A test for equality across the five Protestant identities cannot be rejected at any significance level $(p=.92)$. When nonaffiliated families are compared to all families with a denominational identity (grouped together), the nonaffiliated-any denominational identity probability difference is .034 and the percentage amount difference is .078 ( $p s=.116$ and .126).

If the controls are not included, the estimated patterns in denominational identity are misleading. ${ }^{15}$ There are three important examples. First, in models with no controls, black Protestant families are estimated to be $.144(p<.000)$ less likely to give to necessity organizations than

\footnotetext{
13 The result that Jewish families are both more likely to give and give larger amounts is due to families in which all main decisionmakers are Jewish (i.e., couples where both the man and woman are Jewish, and single-headed families where the single head is Jewish) and couples in which the man is Jewish but the woman is not. There is no evidence that couples in which the woman is Jewish, but the man not, give more.

${ }^{14}$ Jewish families are more likely to give and give larger amounts than both Conservative nontraditional and MuslimBuddhist-other families, but the standard errors on these differences are large because of the small numbers of these families in the data. Steensland et al.'s (2000) “Conservative nontraditional” category includes Latter Day Saints/Mormons, Jehovah's Witnesses, and Christian Scientists. The PSID codes Muslims, Buddhists, Hindus, etc. together in an "other" category, obviously limiting the interpretation of results.

${ }^{15}$ In addition to income and wealth, the controls significantly related to giving are education, cohort, ethnicity, being married, being single and female, the age of the youngest child in the family, and living in a big city. See note to Table 3 for list of all controls included in the model.
} 
Catholic families, but this difference vanishes upon adding controls for income and wealth. Second, in models with no controls, mainline Protestant families are estimated to be .048 ( $p=.02)$ more likely to give to necessity organizations than Catholic families, but this difference vanishes upon adding controls for cohort and Hispanic ethnicity. ${ }^{16}$ Third, in models with no controls, the differences between Jewish families and families with other denominational identities are much larger (e.g., .231 more likely to give, $p<.000$ )—adding the controls reduces the difference to .08, but the difference does not vanish. In short, patterns of giving across denominational identities based on simple statistics—or based on models without good control variables—are misleading. ${ }^{17}$

Table 3 column 2 checks the sensitivity of the results by using a different definition of giving to help people in need. The dependent variable is expanded to include giving to combined purpose and international aid organizations. Because many families contribute to combined purpose funds like the United Way, the fraction of families who give at least once over the three years is much higher (68 percent) as is the conditional median annual gift (\$181) and the conditional mean annual gift (\$456). Most of the results obtained for giving to necessity organizations also obtain when the definition of giving includes combined purpose funds and international aid organizations. However, one result in Table 3 is different. There is no longer evidence that nonaffiliated families are more likely to give and give larger amounts. ${ }^{18,19}$

When the definition of giving is expanded, estimates of the difference between Jewish families and other families are robust. Jewish families are more likely to give and give higher amounts (conditional on giving) than Catholic families. The probability of giving is .058 higher, the conditional amount is 25.5 percent higher, and the estimates are much more precise (the $p$-values are .005 and .015). The difference between Jewish families and evangelical Protestant families is the same as the Jewish-Catholic difference (and just as precisely estimated). The difference between Jewish families and mainline Protestant families is slightly larger ( $p s<.01$ ). Results are qualitatively similar if we switch from a double-log specification of income to giving as a cubic function of income, a cubic function of wealth (not including home equity), and a cubic function of home equity. ${ }^{20}$

Also, I check the results by estimating a Tobit model of giving to human service and international organizations using data from the 1996 GSS (not shown, but available upon request). This checks to see if the PSID results are sensitive to the use of approximate Steensland et al. (2000) categories, and to any families switching denominational identity during the panel (between the

\footnotetext{
${ }^{16}$ Older cohorts are more likely to give to necessity organizations and Hispanic families less likely. Ethnicity is not examined in detail, but Osili and Du (2005) find that (i) new immigrants are more likely than the native-born to give money to family members and less likely to give to charitable organizations, but (ii) after a decade in the United States, immigrants are just as likely as natives to give to charitable organizations.

${ }^{17}$ Data quality of PSID income and wealth measures are high (see Gouskova and Schoeni 2007; Juster, Smith, and Stafford 1999)

${ }^{18}$ I reestimated the models in Table 3 splitting the Conservative nontraditional identity into its Mormon $(n=56)$ and Jehovah's Witness $(n=46)$ components. Jehovah's Witness families are more likely to give to necessity organizations (coeff. $=.151, p=.08$ ) and to give larger amounts conditional on giving (41 percent larger, though the $p$-value $=$ .16). However, these results vanish when the definition of giving is expanded to include combined purpose funds and international aid organizations, and also is absent in the analysis of donations to help the victims of the tsunami (to be discussed in the next section). None of the models produce evidence that Mormon families give more, but one should keep in mind the small sample size for Mormons (and Jehovah's Witnesses).

${ }^{19}$ In column 2, the difference between Muslim-Buddhist-other and black Protestant families is now statistically significant.

${ }^{20}$ The Jewish-Catholic difference in the probability of giving to necessity organizations estimated using the cubic functional form is somewhat higher than in Table 3 column 1a, but less precisely estimated $(.105, p=.138)$. The estimated difference in amounts given (\$59) is nearly identical to that implied by the elasticity in Table 3 column $1 \mathrm{~b}$ when applied to the average amount given $(.201 \times \$ 271=\$ 54)$, although again the difference using the cubic is less precisely estimated. A similar pattern emerges with the expanded definition of giving. The probability difference is $.102(p=.103)$ and the difference in the amounts is $\$ 97$ (compare to $.255 \times \$ 456=\$ 116$ from the double-log in Table 3 column $2 b$ ).
} 
year denominational identity is queried and the year giving is queried). The 1996 GSS queries denominational identity and giving in the same survey year so denominational switching does not affect the results. The GSS results are very similar to the results in Table 3 column 2, suggesting that the PSID's approximation to the exact Steensland et al. (2000) classification and any undetected switching in the panel is not substantial enough to be affecting the results. ${ }^{21}$

Finally, I check the sensitivity of the results using Center Panel data describing donations to help the victims of the tsunami that struck Southeast Asia in December 2004. Because the Center Panel also collected data regarding whether or not respondents made tsunami donations through places of worship, these data permit three checks of the potential special collections problem in Table 3. First, if the basic necessities question missed substantial amounts donated through special collections at places of worship then the Table 3 basic necessities results would be very different from the tsunami results that capture such giving, but they are not. Second, if the basic necessities question missed substantial amounts donated through special collections, then we would expect a different pattern across the different denominations. Adding a "donated-totsunami-through-place-of-worship" variable, interacted with denominational identity, produces a set of proxy controls for the different patterns and should change the Table 3 results, but it does not. Third, consider an extreme version of the potential special collection problem: special collections for necessity organizations generate large donations, but none of these donations are reported in response to the direct question about basic necessity giving. Artificially mimicking this problem in the tsunami model suggests that the estimates in Table 3 columns $1 \mathrm{a}$ and $1 \mathrm{~b}$ could be at most on the order of 29 percent and 42 percent too high (e.g., the estimated Jewish-Catholic differences would be $.081 \times .71=.058$ and $.201 \times .58=.117)$. In short, two checks of the special collections problem fail to find a problem, and even mimicking an extreme version of the potential problem suggests the qualitative difference regarding Jewish families would remain intact.

\section{Attendance}

Table 4 column 1 presents results from a Tobit model in which interactions between the denominational identities and frequent attendance at worship services are added to the model. In families headed by a single adult, a frequently attending family is defined to be one in which the adult attends twice per month or more, averaged over the 2002 and 2004 years. In married-couple families, a frequently attending family is defined as one in which both the man and woman attend twice per month or more, again averaged over the 2002 and 2004 years. The independent variables presented in the table are the denominational identities and identities interacted with the indicator of frequent attendance (the full set of additional controls are included). The omitted reference group is Catholic families who infrequently attend.

Column 1 extends the results from Table 3 in an interesting way. Five of the denominational identity coefficients are noticeably larger (nonaffiliated, mainline Protestant, Jewish, no-denomination Protestant, and Conservative nontraditional) and all of these are now statistically significant. In addition, three of the interaction variables have large coefficients (black Protestant, evangelical, and Catholic families) that are also statistically significant. Two other interaction variables are large (Jewish and Conservative nontraditional families) though not precisely estimated.

Whether the respondent family frequently attends matters more for some denominational identities than others. For example, infrequently attending black Protestant families are no more

\footnotetext{
${ }^{21}$ I also reestimated the models from Table 3 using the PSID subsample whose denominational identity was queried when they were 36 years old or older ( 50 percent of the full sample). There are some small differences in point estimates and reduced precision in the column 1 results, but the column 2 results with the subsample are nearly identical to those in Table 3 with one exception. The coefficients for black Protestant families are more negative and significant.
} 
Table 4: Tobit models of amounts given over three years to organizations that help people with basic necessities: Frequent attendance

\begin{tabular}{|c|c|c|c|c|}
\hline \multirow[b]{2}{*}{ Independent Variables } & \multicolumn{2}{|c|}{ Tobit (1) } & \multicolumn{2}{|c|}{ Tobit (2) } \\
\hline & $\begin{array}{l}\text { Probability } \\
\text { of } \\
\text { Giving } \\
\text { (a) }\end{array}$ & $\begin{array}{l}\text { Log Amount } \\
\text { Conditional } \\
\text { on Giving } \\
\text { (b) }\end{array}$ & $\begin{array}{l}\text { Probability } \\
\text { of } \\
\text { Giving } \\
\text { (a) }\end{array}$ & $\begin{array}{l}\text { Log Amount } \\
\text { Conditional } \\
\text { on Giving } \\
\text { (b) }\end{array}$ \\
\hline \multirow[t]{2}{*}{ Nonaffiliated } & $.093^{* * *}$ & $.228^{* * *}$ & $.049^{* *}$ & $.116^{* *}$ \\
\hline & $(.028)$ & $(.074)$ & $(.024)$ & $(.058)$ \\
\hline \multirow[t]{2}{*}{ Black Protestant } & -.003 & -.008 & .008 & .017 \\
\hline & $(.052)$ & $(.116)$ & $(.043)$ & $(.098)$ \\
\hline \multirow[t]{2}{*}{ Evangelical Protestant } & .022 & .050 & - & - \\
\hline & $(.032)$ & $(.013)$ & & \\
\hline \multirow[t]{2}{*}{ Mainline Protestant } & $.051^{*}$ & $.119^{*}$ & - & - \\
\hline & $(.030)$ & $(.072)$ & & \\
\hline \multirow[t]{2}{*}{ Catholic } & - & - & .000 & .001 \\
\hline & & & $(.021)$ & $(.047)$ \\
\hline \multirow[t]{2}{*}{ Jewish } & $.116^{* * *}$ & $.297^{* *}$ & $.082^{* *}$ & $.203^{*}$ \\
\hline & $(.041)$ & $(.122)$ & $(.039)$ & $(.106)$ \\
\hline \multirow[t]{2}{*}{ No-denomination Protestant } & $.079^{* *}$ & $.193^{*}$ & .037 & .088 \\
\hline & $(.039)$ & $(.102)$ & $(.036)$ & $(.087)$ \\
\hline \multirow[t]{2}{*}{ Conservation nontraditional } & $.187^{* *}$ & $.536^{*}$ & .047 & .111 \\
\hline & $(.075)$ & $(.284)$ & $(.056)$ & $(.140)$ \\
\hline \multirow[t]{2}{*}{ Muslim, Buddhist, other } & .056 & .135 & .040 & .094 \\
\hline & $(.069)$ & $(.176)$ & $(.055)$ & $(.136)$ \\
\hline Frequent attendance & $.102^{* *}$ & $.207^{* *}$ & - & - \\
\hline \multirow{3}{*}{$\begin{array}{l}\text { Black Protestant } \\
\text { Evangelical Protestant }\end{array}$} & $(.044)$ & $(.091)$ & & \\
\hline & $.080^{* * *}$ & $.167^{* * *}$ & $.051^{* *}$ & $.109^{* *}$ \\
\hline & $(.029)$ & $(.060)$ & $(.022)$ & $(.048)$ \\
\hline \multirow[t]{2}{*}{ Mainline Protestant } & .033 & .070 & - & - \\
\hline & $(.033)$ & $(.069)$ & & \\
\hline \multirow[t]{2}{*}{ Catholic } & $.109^{* * *}$ & $.224^{* * *}$ & - & - \\
\hline & $(.030)$ & $(.063)$ & & \\
\hline \multirow[t]{2}{*}{ Jewish } & .112 & .300 & - & - \\
\hline & $(.109)$ & $(.331)$ & & \\
\hline \multirow[t]{2}{*}{ No-denomination Protestant } & .070 & .161 & - & - \\
\hline & $(.157)$ & $(.389)$ & & \\
\hline \multirow[t]{2}{*}{ Conservation nontraditional } & -.161 & -.380 & - & - \\
\hline & $(.112)$ & $(.281)$ & & \\
\hline \multirow[t]{2}{*}{ Muslim, Buddhist, other } & .099 & .225 & - & - \\
\hline & $(.107)$ & $(.249)$ & & \\
\hline Pseudo $R^{2}$ & \multicolumn{2}{|c|}{.085} & \multicolumn{2}{|c|}{.083} \\
\hline
\end{tabular}

Note: The dependent variable is the logarithm of the three-year average (2000,2002, and 2004) of giving to organizations that help people in need of food, shelter, or other basic necessities. The independent variables are those shown in the table plus those described in Table 3. The estimates are from weighted Tobit models. In the specification in column 1, the omitted reference category is Catholic families who infrequently attend. In the specification in column 2, the omitted reference category is all mainline Protestant families (infrequent and frequent attenders) and evangelical Protestant families who infrequently attend. Columns 1a and $2 \mathrm{a}$ present estimates of the marginal effect on the probability of giving. Columns $1 \mathrm{~b}$ and $2 \mathrm{~b}$ present the marginal effect on the log amount given, conditional on that amount being greater than zero. The marginal effects of the interactions are calculated taking the nonlinearity of the Tobit model into account (Ai and Norton 2003).

${ }^{*} p<.10 ;{ }^{* *} p<.05 ;{ }^{* * *} p<.01$. 
likely to give than infrequently attending Catholic families, but frequently attending black Protestant families have an estimated probability of giving to necessity organizations that is .102 higher $(p=.02)$. Attendance also matters more for evangelical and Catholic families. In contrast, infrequently attending mainline Protestant families have a higher estimated probability of giving than infrequently attending Catholic families $(.051, p=.09)$, but for frequently attending mainline Protestant families the additional (to the .051) probability of giving is only .033 higher and is not significant. Infrequently attending Jewish families have a higher estimated probability of giving than infrequently attending Catholic families $(.116, p=.01)$. Frequently attending Jewish families have an even higher probability (by an additional .112), but the estimate is not precise. $^{22}$

The attendance result reveals a methodological lesson. Specifications that interact denominational identity with behavior-oriented religiosity measures may selectively exaggerate differences between some denominational identities. Consider Table 4 column 2 where only the attendance by evangelical Protestant interaction is included. Doing so forces infrequently attending evangelical Protestants into the omitted reference group with all mainline Protestants (both frequently attending and infrequently attending). The omitted reference in this analysis is mainline Protestant so that the evangelical-mainline comparison is more directly apparent in the table. The evangelicalmainline difference in the probability of giving is $.051(p=.02)$, but must be interpreted as the difference between (i) frequently attending evangelical Protestants and (ii) all mainline Protestants plus infrequently attending evangelical Protestants. Going back to Table 3 column 1a, the difference in the probability of giving between all evangelical Protestants and all mainline Protestants is negligible (.008) and not statistically significant. From Table 4, column 1a the difference in the probability of giving between frequently attending evangelical Protestants and frequently attending mainline Protestants is .017, again small and not statistically significant. ${ }^{23}$

The point is that how one defines the omitted reference group affects the interpretation of the estimates. The result in column 2a replicates Regnerus, Smith, and Sikkink's (1998: Table 2 Model 5) finding that evangelical Protestants who frequently attend church are more likely to give to organizations that help people who are poor. But the result in column 1a goes deeper by showing that the column 2 a result depends on combining infrequently attending evangelical Protestants and frequently attending mainline Protestants with infrequently attending mainline Protestants into the omitted reference group. Separate all these groups out (as in column 1a) and the overall evangelical-mainline difference all but vanishes. Hence, interacting a behaviororiented religiosity measure with one denominational identity but not another can create an apparent difference between the identities. ${ }^{24,25}$

\footnotetext{
${ }^{22}$ Linear probability models produce similar results, indicating that a few families giving large amounts do not drive the results. Similar results obtain if I define the frequently attending couples as either the man or the woman frequently attends.

${ }^{23}$ Not surprisingly, the model in Table 4 column 2 is rejected in favor of the model in column 1 ( $\left.p=.003\right)$.

24 This may be happening with Regnerus, Smith, and Sikkink's (1998) variable that indicates whether the respondent uses conservative voting organizations like the Christian Coalition to help decide how to vote. That variable essentially splits fundamentalist and evangelical Protestants into two groups: (1) those who vote and use the help of conservative voting organizations and (2) those who do not vote or who vote but do not use the help of conservative voting organizations. Group (1) are the givers. In contrast, the conservative voting variable does not similarly split other denominational identities (e.g., mainline Protestants, Catholics) into two groups that differ according to their giving behavior. See Mockabee, Wald, and Leege (2007) for a variable that splits mainline Protestants and Catholics into two groups that may be useful in the analysis of giving to necessity organizations.

25 The point estimates on attendance for black Protestants and evangelicals, relative to the attendance point estimate for mainline Protestants, are not different enough to be statistically significant. However, the attendance estimates for mainline Protestant and Catholic families are different enough to attain statistical significance $(p=.087)$.
} 


\section{Is Giving to Help People in Need Associated with Other Kinds of Generosity?}

I answer this question by adding as independent variables two measures of generosity: religious giving (i.e., to churches, synagogues, mosques, etc.) and other secular giving (i.e., to education, health, the arts, etc.) to the models reported in Table 3 column 2. Full details of the results are available upon request. The model is a "tradeoff regression" in the sense that one can estimate the overall tradeoff between giving to organizations that help people in need and the other two kinds of giving. A causal interpretation of the coefficients is not appropriate (see Wooldridge 2009:549-50).

First, I find positive associations between giving to necessity organizations and both religious giving and other secular giving. There is no evidence of a tradeoff in the sense of a negative and significant relationship between giving to necessity organizations and the other kinds of giving. Second, the association between other secular giving and giving to necessity organizations is larger than the association between religious giving and giving to necessity organizations. In addition, these results also obtain within each denominational identity, when I estimate the model separately for the black Protestant families, evangelical Protestant families, etc., with a few exceptions (e.g., not surprisingly I find no association between religious giving and giving to necessity organizations for nonaffiliated families and no-denomination Protestant families).

In the trade-off regressions, Jewish families give more to necessity organizations. The probability and conditional mean differences between Jewish and Catholic families are .039 and .168 ( $p s=.043$ and .069). These differences are smaller than those appearing in Table 3 because the differences now compare Jewish and Catholic families who give the same amounts both to their synagogue/church and to other secular organizations.

\section{Discussion ANd Conclusions}

Simple statistics from a single calendar year mask considerable heterogeneity among families that give to organizations that help people with necessities. In a single year, 29 percent of American families give to basic necessity organizations, but this 29 percent is made up of three groups: 30 percent are occasional givers who gave in only one of the three years observed, 37 percent are families who gave in two of the years, and 33 percent are regular givers who gave in all three years. Among the 29 percent who give in a single year, the median family gives $\$ 200$ and the average is $\$ 490$. Among the 53 percent of families who give at least once over the three years, the median giving is $\$ 105$ (per year) and the average is $\$ 270$. It is a mistake to think of the families who give to necessity organizations in any single year as a homogeneous group. This has obvious implications for researchers who have to work with single-year cross-sections. There is a practical implication as well; those interested in increasing the amount given to necessity organizations must consider how to transform occasional givers into regular givers, an idea emphasized by Smith, Emerson, and Snell (2008:91ff).

I identify two methodological issues as well. First, although simple descriptions of giving to basic necessity organizations reveal differences across Christian denominational identities, these differences disappear when other differences in income, wealth, ethnicity, etc. are controlled.

Taking the point estimates at face value, the finding that frequent attendance is associated with more giving to necessity organizations for evangelical Protestant and black Protestant families but not for mainline Protestant families is consistent with a prediction from Iannaccone's $(1988,1992)$ church-sect theory (I thank Russell James for pointing this out). Specifically, among all denominational identities attendance implies an endorsement of the denomination's norms, but in more conservative denominations these norms include stronger behavioral requirements. Of course, the attendance interaction effect is consistent with other arguments about unobserved characteristics as well. Attendance tells us something about an unobserved characteristic of a person and that "something" differs across persons with different denominational identities. 
Drawing substantive conclusions based on simple statistics that do not control for other differences across denominational identities is a mistake. Second, splitting evangelical families into two groups (frequent attenders and infrequent attenders) and combining the infrequently attending evangelical families with all mainline families (both frequent attenders and infrequent attenders) creates an apparent difference in giving between evangelical families and mainline families. Interacting a behavior-oriented religiosity measure with one denominational identity but not the other may produce an apparent difference between the denominational identities that does not exist. Therefore, always use fully interacted models.

Although giving to necessity organizations measured over multiple years $(2000,2002$, and 2004) does not differ across Christian denominational identities, giving does differ by denominational identity in one main way. Even in the presence of controls, Jewish families are both more likely to give - by 8 percentage points - and, when they do give, give larger amounts - 20 percent larger. These are large differences. The 8 percentage points are relative to a base of 53 percent of families who give at least once over the three years, and hence represent a 15 percent increase $(8 / 53)$ in the number of families who give. The 20 percent applied to the national average of $\$ 271$ (conditional on families who give) yields $\$ 54$ per year. Opinions may differ as to whether these are large magnitudes. But I think that if there was in hand an effective persuasion that could increase the number of families who give by 15 percent and increase the amount given by $\$ 54$ per year per family who gives, those hoping to increase giving to basic necessity organizations would be interested in achieving such results.

These results come from Center Panel data that have several advantages. A survey question focused specifically on giving to basic necessity organizations, data on dollar amounts-giving, income, and wealth - and other controls, multiple years of prospectively collected data, and mitigated social presentation effects. The results are robust to expanding the definition of giving, to the use of various estimation methods, and to checks for the possibility that some giving to necessity organizations is given through special collections at places of worship. ${ }^{26}$

However, the mainline-evangelical-black Protestant classification (Steensland et al. 2000) in the PSID is "approximate." Also there may have been some denominational switching between the time the PSID queried denomination and when the giving questions were asked. However, using an exact classification in the GSS, I found the same results. I also obtain similar results when the PSID is restricted to a subsample of respondents whose denominational identity is queried at age 36 and older (the switching problem is mitigated). A second qualification is that no analysis was done for volunteering through necessity organizations. This too helps people in need and is an important area for future research. ${ }^{27}$

The results have several implications. First, the finding that families with a denominational identity do not give more to basic necessity organizations than nonaffiliated families suggests that without changes within denominations, faith-based policy initiatives that encourage religiously affiliated people to do poverty alleviation may not enjoy a special advantage over other policy initiatives that encourage nonaffiliated people to do poverty alleviation.

Second, an alternative to faith-based policy initiatives would be to focus on the reasons why some denominational identities give more than others to necessity organizations, and to see

\footnotetext{
${ }^{26}$ Although I make progress on the "special collections problem," further work on this is an important area for future research.

${ }^{27}$ Of course, a third qualification is that the results are about giving through organizations, not about giving directly to people in need. I analyzed GSS data from 1996, 2002, and 2004 about giving directly to people in need. The results (available upon request) are mixed. The clearest result is that black Protestants and evangelical Protestants are more likely to give "money, food, or clothing" to a needy neighbor. However (and somewhat inconsistently), they are not more likely to give to a needy relative or a needy friend. Because the percentage of people giving money, food, or clothing to a needy neighbor in the GSS (46 percent) is so much higher than the percentage giving money to nonrelatives ( 2 percent; Schoeni 1997), it is likely that the giving reported in the GSS is predominantly in-kind food and clothing.
} 
if those reasons suggest ideas to encourage giving to necessity organizations that are general enough to be transferrable to families with other denominational identities. Recall there are no differences across Christian denominational identities in giving to necessity organizations. No differences between Protestant families and Catholic families. No differences between mainline Protestant families and evangelical Protestant families. These results are consistent with my argument that, using criteria drawn from the social science literature about effective frames to encourage generosity, statements from many different kinds of Christian denominations about giving are not effective. Therefore, a possible explanation for the religious incongruence found here (Chaves 2010) is that, just as denominational statements are not effective frames to encourage giving to necessity organizations, perhaps congregations are also not effective in encouraging members to internalize generosity toward necessity organizations (i.e., making that generosity part of the member's religious identity) or in embedding members in a group in which that generosity is expected. Testing this conjecture would require taking the effectiveness hypothesis to the congregational level; are there congregations whose worship services, sermons, educational material, etc. encourage generosity using frames predicted from the social science literature to be effective, and do members of these congregations give more to necessity organizations? Carrying out this work would not only provide a further test of the effectiveness hypothesis, but also might lead to new theoretical explanations for the empirical patterns I have found.

The result that Jewish families are both more likely to give and give larger amounts is consistent with the argument that the Jewish philanthropy literature does use effective frames to encourage generosity. To learn whether it is, in fact, the use of empathic other-oriented induction, incorporating giving to help people in need into one's religious identity, universalism, and making giving to help people in need a community norm that explain larger giving by Jewish families requires a research agenda using qualitative methods and population surveys that include an oversample of Jewish families. Of course, a population survey with a Jewish oversample may confirm the higher Jewish giving reported herein, and also allow further analysis of the level of giving across orthodox, conservative, and reformed Jewish families. The research agenda also should generate knowledge about other possible factors such as Jewish religious practices, the transmission of giving behavior from parents to children, and translational research to examine whether the causes of higher giving by Jewish families might suggest ideas that can be transferred to other religious identities that would effectively encourage giving to organizations that help people in need.

\section{REFERENCES}

Ai, Chunrong and Edward C. Norton. 2003. Interaction terms in logit and probit models. Economics Letters 80(1):123-29. Aquino, Karl and Americus Reed, II. 2002. The self-importance of moral identity. Journal of Personality and Social Psychology 83(6):1423-40.

Batson, C. Daniel. 1991. The altruism question: Toward a social-psychological answer. Hillsdale, NJ: Lawrence Erlbaum.

- 1998. Altruism and prosocial behavior. In The handbook of social psychology, 4th ed., Vol. 2, edited by Daniel T. Gilbert, Susan T. Fiske, and Gardner Lindzey, pp. 463-84. New York: Oxford University Press.

Bekkers, René. 2007. Measuring altruistic behavior in surveys: The all-or-nothing dictator game. Survey Research Methods 1(3):139-44.

Bekkers, René and Theo Schuyt. 2008. And who is your neighbor? Explaining denominational differences in charitable giving and volunteering in the Netherlands. Review of Religious Research 50(1):74-96.

Bénabou, Roland and Jean Tirole. 2006. Incentives and prosocial behavior. American Economic Review 96(5): $1652-78$.

Benedict XVI, Pope. 2009. Caritas in veritate [Charity in truth]. Rome, Italy: Libreria Editrice Vaticana.

Biddle, Jeff E. 1992. Religious organizations. In Who benefits from the nonprofit sector? edited by Charles T. Clotfelter, pp. 92-133. Chicago, IL: University of Chicago Press.

Brooks, Arthur C. 2006. Who really cares: America's charity divide-Who gives, who doesn't and why it matters. New York: Basic Books.

Brown, Eleanor and James M. Ferris. 2007. Social capital and philanthropy: An analysis of the impact of social capital on individual giving and volunteering. Nonprofit and Voluntary Sector Quarterly 36(1):85-99. 
Bush, Lawrence and Jeffrey Dekro. 1993. Jews, money and social responsibility: Developing a "Torah of money" for contemporary life. Philadelphia, PA: Shefa Fund.

Chaves, Mark. 2004. Congregations in America. Cambridge, MA: Harvard University Press.

- 2010. Rain dances in the dry season: Overcoming the religious congruence fallacy. Journal for the Scientific Study of Religion 49(1):1-14.

Davis, James Allan and Tom W. Smith. 2007. General social surveys, 1972-2006 [machine-readable data file]. Principal Investigator, James A. Davis; Director and Co-Principal Investigator, Tom W. Smith; Co-Principal Investigator, Peter V. Marsden. Sponsored by the National Science Foundation. -NORC ed.- Chicago: National Opinion Research Center [producer]; Storrs, CT: The Roper Center for Public Opinion Research, University of Connecticut [distributor].

Dorff, Elliot N. 2005. The way into tikkun olam (repairing the world). Woodstock, VT: Jewish Lights Publishing.

Dovidio, John F., Jane A. Piliavin, David A. Schroeder, and Louis A. Penner. 2006. The social psychology of prosocial behavior. Mahwah, NJ: Lawrence Erlbaum.

Eckel, Catherine C. and Philip J. Grossman. 2004. Giving to secular causes by the religious and nonreligious: An experimental test of the responsiveness of giving to subsidies. Nonprofit and Voluntary Sector Quarterly 33(2):27189.

Eisenberg, Nancy and Richard A. Fabes. 1998. Prosocial development. In Handbook of child psychology, 5th ed., Vol. 3, edited by Nancy Eisenberg, pp. 701-78. New York: Wiley.

Eisenberg, Nancy and Paul H. Mussen. 1989. The roots of prosocial behavior in children. Cambridge, MA: Cambridge University Press.

Eisenberg-Berg, Nancy and Elizabeth Geisheker. 1979. Content of preaching and power of the model/preacher: The effect on children's generosity. Developmental Psychology 15(2):168-75.

Ekeh, Peter P. 1974. Social exchange theory: The two traditions. Cambridge, MA: Harvard University Press.

Fitzgerald, John, Peter P. Gottschalk, and Robert Moffitt. 1998. An analysis of sample attrition in panel data: The Michigan panel study of income dynamics. Journal of Human Resources 33(2):251-99.

Gouskova, Elena. 2007. Weights in the 2005 PSID. Ann Arbor, MI: University of Michigan Institute for Social Research.

Gouskova, Elena and Robert F. Schoeni. 2007. Comparing estimates of family income in the Panel Study of Income Dynamics and the March Current Population Survey, 1968-2005. Ann Arbor, MI: University of Michigan Institute for Social Research. Available at: http://PSIDonline.isr.umich.edu/Publications/Papers/ Report_on_ income_quality_v3.pdf, accessed July 13, 2010.

Grusec, Joan E. 1991. The socialization of altruism. In Prosocial behavior, Vol. 12, edited by Margaret S. Clark, pp. 9-33. Newbury Park, CA: Sage Publications.

Grusec, Joan E. and Erica Redler. 1980. Attribution, reinforcement, and altruism: A developmental analysis. Developmental Psychology 16(5):525-34.

Heilman, Sammuel C. 1991. Tzedakah: Orthodox Jews and charitable giving. In Contemporary Jewish philanthropy in America, edited by Barry A. Kosmin and Paul Ritterband, pp. 133-44. Savage, MD: Rowman and Littlefield Publishers.

Hill, Martha S. 1992. The panel study of income dynamics. Newbury Park, CA: Sage. Available at: http://PSIDonline. isr.umich.edu/Guide/UG/tablcont.html, accessed July 13, 2010.

Hodgkinson, Virginia A. and Murray S. Weitzman. 1992. From belief to commitment: The community service activities and finances of religious congregations in the United States, Findings from a national survey. Washington, DC: Independent Sector.

Hoffman, Martin L. 2000. Empathy and moral development: Implications for caring and justice. Cambridge, MA: Cambridge University Press.

Iannaccone, Laurence R. 1988. A formal model of church and sect. American Journal of Sociology 94: S24168.

1992. Sacrifice and stigma: Reducing free-riding in cults, communes, and other collectives. Journal of Political Economy 100(2):271-91.

Jackson, Timothy P. 2003. The priority of love: Christian charity and social justice. Princeton, NJ: Princeton University Press.

Juster, F. Thomas, James P. Smith, and Frank Stafford. 1999. The measurement and structure of household wealth. Labour Economics 6:253-75.

Keister, Lisa A. 2003. Religion and wealth: The role of religious affiliation and participation in early adult asset accumulation. Social Forces 82(1):175-207.

2008. Conservative Protestants and wealth: How religion perpetuates asset poverty. American Journal of Sociology. 113(5):1237-71.

Lakoff, George. 2002. Moral politics: How liberals and conservatives think, 2nd ed. Chicago, IL: University of Chicago Press.

Lévy-Garboua, Louis, Claude Meidinger, and Benoît Rapoport. 2006. The formation of social preferences. In The handbook of the economics of giving, altruism and reciprocity, Vol. 1, edited by Serge-Christophe Kolm and Jean Mercier Ythier, pp. 545-613. Amsterdam, The Netherlands: New Holland. 
Mills, Rosemary S. L. and Joan E. Grusec. 1989. Cognitive, Affective and behavioral consequences of praising altruism. Merrill-Palmer Quarterly 35(3):299-326.

Mockabee, Stephen T., Kenneth D. Wald, and David C. Leege. 2007. Reexamining religiosity: A report on the new religion items in the 2006 ANES pilot study. Cincinnati, OH: University of Cincinnati.

Neusner, Jacob. 1982. Tzedakah: Can Jewish philanthropy buy Jewish survival? Chappaqua, NY: Rossel Books.

Okten, Cagla and Una Okonkwo Osili. 2007. Preferences for international redistribution. Indianapolis, IN: Indiana University-Purdue University Indianapolis.

Oliner, Samuel P. and Pearl M. Oliner. 1988. The altruistic personality: Rescuers of Jews in Nazi Europe. New York: Free Press.

Osili, Una Okonkwo and Dan Du. 2005. Immigrant assimilation and charitable giving. New Directions in Philanthropic Fundraising 48:89-104.

Pew Forum on Religion and Public Life. 2008. U.S. religious landscape survey. Religious affiliation: Diverse and dynamic. Washington, DC: Pew Research Center.

- 2009. Faith in flux: Changes in religious affiliation in the U.S. Washington, DC: Pew Research Center.

Regnerus, Mark D., Christian Smith, and David Sikkink. 1998. Who gives to the poor? The influence of religious tradition and political location on the personal generosity of Americans toward the poor. Journal for the Scientific Study of Religion 37(3):481-93.

Ribar, David C. and Mark O. Wilhelm. 2006. Exchange, role modeling and the intergenerational transmission of elder support attitudes: Evidence from three generations of Mexican-Americans. Journal of Socio-Economics 35(3):51431.

Ritterband, Paul. 1991. The determinants of Jewish charitable giving in the last part of the twentieth century. In Contemporary Jewish philanthropy in America, edited by Barry A. Kosmin and Paul Ritterband, pp. 57-72. Savage, MD: Rowman and Littlefield Publishers.

Rooney, Patrick M. and Melissa S. Brown. 2007. Patterns of household charitable giving by income group, 2005. Research report. Indianapolis, IN: Center on Philanthropy at Indiana University.

Rooney, Patrick M., Melissa S. Brown, and Ke Wu. 2007. Are donors stable over time? Paper presented at the 36th Annual Conference of the Association for Research on Nonprofits and Voluntary Action, Atlanta, GA, November 17, 2007.

Saroglou, Vassilis, Isabelle Pichon, Laurence Trompette, Marijke Verschueren, and Rebecca Dernelle. 2005. Prosocial behavior and religion: New evidence based on projective measures and peer ratings. Journal for the Scientific Study of Religion 44(3):323-48.

Schoeni, Robert F. 1997. Private interhousehold transfers of money and time: New empirical evidence. Review of Income and Wealth 43(4):423-48.

Schwartz, Shalom H. 1992. Universals in the content and structure of values: Theoretical advances and empirical tests in 20 countries. In Advances in experimental social psychology, Vol. 25, edited by Mark P. Zanna, pp. 1-65. San Diego, CA: Academic Press.

Sherkat, Darren E. 1991. Leaving the faith: Testing theories of religious switching using survival models. Social Science Research 20(2):171-87.

Sider, Ronald J. 1999. Just generosity. Grand Rapids, MI: Baker Books.

Silverman, Ira. 1991. The new Jewish philanthropies. In Contemporary Jewish philanthropy in America, edited by Barry A. Kosmin and Paul Ritterband, pp. 205-16. Savage, MD: Rowman and Littlefield Publishers.

Smith, Adam. [1759] 1976. Theory of moral sentiments. In The Glasgow edition of the works and correspondence of Adam Smith, Vol. 1, edited by David D. Raphael and Andrew Skinner. Oxford, UK: Clarendon Press.

Smith, Christian, Michael O. Emerson, and Patricia Snell. 2008. Passing the plate: Why American Christians don't give away more money. New York: Oxford University Press.

Spilka, Bernard, Ralph W. Hood, Jr., Bruce Hunsberger, and Richard Gorsuch. 2003. The psychology of religion, 3rd ed. New York: Guilford.

Stafford, Frank P., Robert F. Schoeni, Jacquelynne S. Eccles, Katherine McGonagle, Wei-Jun Jean Yeung, and Robert B. Wallace. 2005. The Panel Study of Income Dynamics Wave XXXIV [machine-readable data file]/Director and Principle Investigator, Frank P. Stafford; Associate Director and Principle Investigator Robert F. Schoeni; CoPrinciple Investigators, Jacquelynne S. Eccles, Katherine McGonagle, Wei-Jun Jean Yeung, and Robert B. Wallace. Ann Arbor, MI: Institute for Social Research, The University of Michigan.

Steensland, Brian, Jerry Z. Park, Mark D. Regnerus, Lynn D. Robinson, W. Bradford Wilcox, and Robert D. Woodberry. 2000. The measure of American religion: Toward improving the state of the art. Social Forces 79(1):291318.

Tan, Jonathan H. W. 2006. Religion and social preferences: An experimental study. Economics Letters 90(1):60-67.

Tobin, Gary A. 2001. The transition of communal values and behavior in Jewish philanthropy. San Francisco, CA: Institute for Jewish and Community Research.

Wilhelm, Mark O. 2006. New data on charitable giving in the PSID. Economics Letters 92(1): 26-31.

- 2007. The quality and comparability of survey data on charitable giving. Nonprofit and Voluntary Sector Quarterly 36(1):65-84 
Wilhelm, Mark O. and René Bekkers. 2010. Helping behavior, dispositional empathic concern, and the principle of care. Social Psychology Quarterly 73:11-32.

Wilhelm, Mark O., Eleanor Brown, Patrick M. Rooney, and Richard Steinberg. 2005. The Center on Philanthropy Panel Study [machine-readable data file]/Director and Principal Investigator, Mark O. Wilhelm; Co-Principal Investigators, Eleanor Brown, Patrick M. Rooney, and Richard Steinberg; Sponsored by Atlantic Philanthropies. In the Panel Study of Income Dynamics Wave XXXIV [machine-readable data file] / Director and Principal Investigator, Frank P. Stafford; Associate Director and Principal Investigator Robert F. Schoeni; Co-Principal Investigators, Jacquelynne S. Eccles, Katherine McGonagle, Wei-Jun Jean Yeung, and Robert B. Wallace. Ann Arbor, MI: Institute for Social Research, The University of Michigan.

Woocher, Jonathan. 1986. Sacred survival: The civil religion of American Jews. Bloomington, IN: Indiana University Press.

Wooldridge, Jeffrey M. 2009. Introductory econometrics: A modern approach. Mason, OH: South-Western.

Wuthnow, Robert. 1991. Acts of compassion: Caring for others and helping ourselves. Princeton, NJ: Princeton University Press. 